Volume 3

$12-15-2017$

\title{
The Future of Nuclear Security in Moroccan Territory After the Creation of the New Moroccan Agency of Nuclear and Radiological Safety and Security: Opportunities and Challenges
}

\author{
Amal Touarsi \\ Faculty of Sciences University Ibn Tofail \\ Amina Kharchaf \\ Faculty of Sciences University Ibn Tofail
}

Follow this and additional works at: https://trace.tennessee.edu/ijns

Part of the Defense and Security Studies Commons, Engineering Education Commons, International Relations Commons, National Security Law Commons, Nuclear Commons, Nuclear Engineering Commons, Radiochemistry Commons, and the Training and Development Commons

\section{Recommended Citation}

Touarsi, Amal and Kharchaf, Amina (2017) "The Future of Nuclear Security in Moroccan Territory After the Creation of the New Moroccan Agency of Nuclear and Radiological Safety and Security: Opportunities and Challenges," International Journal of Nuclear Security. Vol. 3: No. 1, Article 13.

https://doi.org/10.7290/ijns030113

Available at: https://trace.tennessee.edu/ijns/vol3/iss1/13

This article is brought to you freely and openly by Volunteer, Open-access, Library-hosted Journals (VOL Journals), published in partnership with The University of Tennessee (UT) University Libraries. This article has been accepted for inclusion in International Journal of Nuclear Security by an authorized editor. For more information, please visit https://trace.tennessee.edu/ijns. 


\title{
The Future of Nuclear Security in Moroccan Territory After the Creation of the New Moroccan Agency of Nuclear and Radiological Safety and Security: Opportunities and Challenges
}

\author{
AMAL TOUARSI \\ PhD Student, Ibn Tofail University, Kenitra, Morocco \\ Dr. AMINA KHARCHAF \\ Professor, Faculty of Sciences, Ibn Tofail University, Kenitra, Morocco
}

\section{Abstract}

Nowadays, a security regime for protecting nuclear and radiological material—providing an intelligent national regulatory institution and establishing national security laws - is necessary in order for a state to ensure security of nuclear and radiological materials used within its borders.

This paper focuses on discussing the opportunities and challenges facing the future of nuclear security after the creation of the new Moroccan Agency of Nuclear and Radiological Safety and Security.

\section{Introduction:}

Considering the benefits of using nuclear and radiological materials to support civilian needs across different areas of society, and considering the rise of nuclear terrorism (especially in the context of a concrete terrorist threat), nuclear security regimes should aim to strike an equilibrium between the secure management of those radiological and nuclear materials and the pursuit of activities that are beneficial to humanity.

More than ever, nuclear security regimes are critical quests not only for the countries developing nuclear programs, but also for countries developing applications using radioactive sources and nuclear material in medicine, industry, food, water, research, and other fields.

Nuclear security is essential because, as well, nuclear security measures maintain an objective of protecting human life, while also preserving health and the environment. 
Therefore, all nations should ensure that such security is not compromised; considering the current global political situation, it cannot be ruled out that nuclear material and other radioactive material could be used for malicious purposes.

For this reason, Morocco is now more aware than ever of the importance of enhancing its nuclear security regime in order to better secure nuclear and radiological material and prevent the proliferation of weapons of mass destruction (WMD), as manifested in its creation of the new Moroccan Agency of Nuclear and Radiological Safety and Security, per law 142-12.

Additionally, herein, we will highlight the discussion of the future of nuclear security throughout Moroccan territory after the creation of the new Moroccan agency. We will also discuss the different opportunities and challenges facing the development of nuclear security while paying mind to study the new law, 142-12, concerning the safety and security of nuclear and radiological material.

\section{The Peaceful Use of Nuclear and Radiological Material Within Moroccan Borders:}

Since the 1970s, nuclear and radiological material has been developed and used in Moroccan territory to support the development of civilian activities.

Apart from the nuclear research reactor TRIGA of $2 \mathrm{MW}$ hosted in the CNESTEN, which is being used to support the production of I-136 and for research — such as the investigation of Mo-99 and another radioisotope - there is, in Tangier, also a category-1 radioactive source: the cobalt-60. This source has a maximum capacity of approximately 100,000 curies, and more than 70 percent of radiological material between 15 percent and 17 percent is used in industry, including category- 2 radiological material such as selenium-75 and iridium-192.

According to statistics produced by the new Moroccan agency, Morocco hosts more than 2,400 pieces of equipment used in the medical field, including a large number of radiological devices and scanners.

\section{International Conventions and Treaties Ratified By Morocco:}

Enhancing security of nuclear and radiological materials to a higher level, thus preventing the proliferation of WMDs and combating and preventing nuclear terrorism threats, is states' top priority. At the international level, Morocco has ratified several international conventions, including treaties (see figure 1).

Table 1. Some Conventions and Treaties Ratified by Morocco

\begin{tabular}{|c|c|c|c|c|}
\hline $\begin{array}{l}\text { Treaties / } \\
\text { Conventions / TC }\end{array}$ & $\begin{array}{l}\text { Codes Entry into } \\
\text { force }\end{array}$ & $\begin{array}{l}\text { Date of signature by } \\
\text { Morocco }\end{array}$ & Ratified by Morocco & $\begin{array}{l}\text { Applicable to } \\
\text { Morocco }\end{array}$ \\
\hline $\begin{array}{l}\text { Treaty on the Non- } \\
\text { Proliferation of } \\
\text { Nuclear Weapons } \\
\text { (T.N.P) }\end{array}$ & $5 / 03 / 1970$ & $1 / 07 / 1968$ & $30 / 07 / 1970$ & $27 / 11 / 1970$ \\
\hline $\begin{array}{l}\text { Application of } \\
\text { safeguards in the } \\
\text { framework of the } \\
\text { Treaty on the Non- } \\
\text { Proliferation of } \\
\text { Nuclear Weapons }\end{array}$ & $18 / 02 / 1975$ & Janv.1973 & $18 / 02 / 1975$ & $30 / 01 / 1993$ \\
\hline Additional Protocol & $16 / 06 / 2004$ & $22 / 09 / 2004$ & $5 / 03 / 2011$ & $21 / 04 / 2011$ \\
\hline
\end{tabular}




\begin{tabular}{|l|l|l|l|l|}
\hline $\begin{array}{l}\text { Agreement on the } \\
\text { Privileges and } \\
\text { Immunities of the } \\
\text { IAEA }\end{array}$ & $30 / 03 / 1977$ & & $17 / 12 / 1976$ & \\
\hline $\begin{array}{l}\text { Convention on Early } \\
\text { Notification of a } \\
\text { Radiological or } \\
\text { Nuclear Accident }\end{array}$ & $27 / 10 / 1986$ & $26 / 09 / 1986$ & $28 / 05 / 1993$ & $7 / 11 / 1993$ \\
\hline $\begin{array}{l}\text { Convention on } \\
\text { Assistance in the } \\
\text { Case of a } \\
\text { Radiological or } \\
\text { Nuclear Accident }\end{array}$ & $26 / 02 / 1987$ & $26 / 09 / 1986$ & $28 / 05 / 1993$ & \\
\hline $\begin{array}{l}\text { Convention on } \\
\text { Nuclear Safety }\end{array}$ & $24 / 10 / 1996$ & $1 / 12 / 1994$ & $7 / 11 / 1993$ \\
\hline $\begin{array}{l}\text { Joint Convention on } \\
\text { the Management of } \\
\text { Spent Fuel and on } \\
\text { the Safety of } \\
\text { Radioactive Waste } \\
\text { Management }\end{array}$ & $29 / 09 / 1997$ & $18 / 06 / 2001$ & \\
\hline $\begin{array}{l}\text { Convention on the } \\
\text { Physical Protection } \\
\text { of Nuclear Material }\end{array}$ & $8 / 02 / 1987$ & & & \\
\hline $\begin{array}{l}\text { Amendment of the } \\
\text { Convention on the } \\
\text { Physical Protection } \\
\text { of Nuclear Material }\end{array}$ & $8 / 05 / 2016$ & $25 / 07 / 1980$ & $23 / 08 / 2002$ & \\
\hline
\end{tabular}

\section{National Legal Framework and Regulations:}

\section{A. Introduction}

Advancing the nuclear security regime nationally provides the legal and institutional framework to protect nuclear and radiological materials during their transport, use, and storage, and these concerns, as well as waste management, are increasingly central in attempts to strengthen and enhance national security.

Nuclear security is particularly critical in today's international security environment, which is characterized by states' increased independence within a more globalized world and by growing threats from subnational groups and terrorist networks that could exploit the benefits of the international community's openness and interconnectedness for criminal purposes [1].

Protecting nuclear and radiological material without forgetting nuclear facilities is an effective and efficient way to prevent, detect, and deter any operation to steal nuclear and radiological materials.

Additionally,, among the most serious challenges facing nuclear security efforts are the striking contrast between the amount of material that would be required to produce a nuclear explosive device (several kilograms) and the quantities of material that have to be secured (several hundred tons) (AIEA).

For these reasons, the Moroccan kingdom has taken an important step toward creating an independent national agency, named the "Moroccan Agency for Nuclear and Radiological Safety and Security," per law 142-12, which aims to enhance and strengthen the country's nuclear security regime. 


\section{B. The Moroccan Agency for Nuclear and Radiological Safety and Security: Missions and Activities}

AMSSNUR, or the Moroccan Agency for Nuclear and Radiological Safety and Security, is an independent agency responsible for establishing and designing national regulations on nuclear security, safety, and the control of transports across Moroccan borders which contain sources of ionizing radiation. The agency thus works to ensure high levels of safety and the protection of nuclear and radiological material.

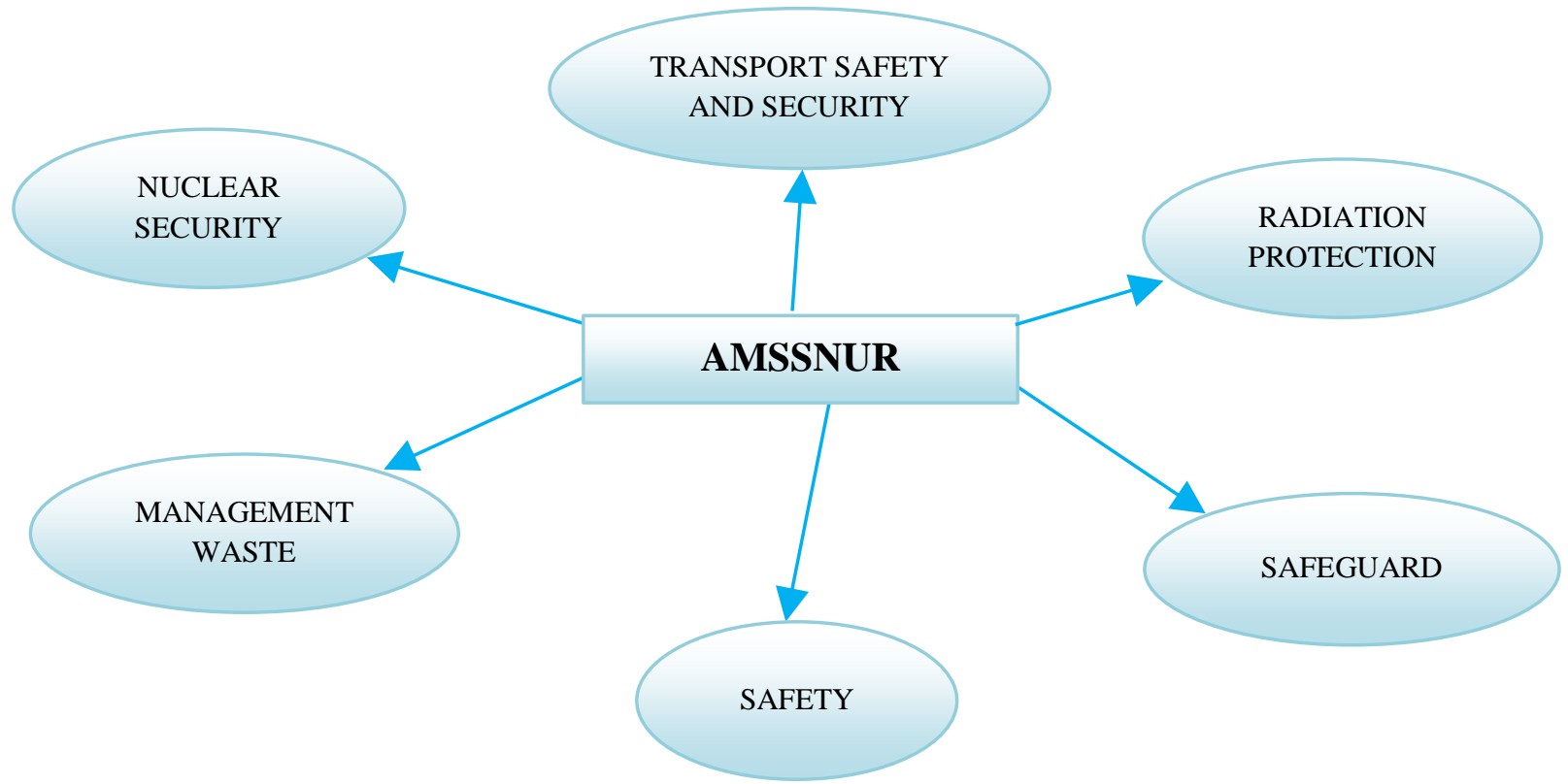

Figure 1. Hierarchy of the Different Activities of AMSSNUR

\section{Law 142-12}

Under the revision of the International Atomic Energy Agency (IAEA), Morocco has previously established laws and regulations, such as the law of October 1971, which is the basic regulation against ionizing radiation and which regulates radiation protection. Establishing and designing regulations is, however, a primary responsibility of the state.

Furthermore, the enhancement and strengthening of the nuclear security regime is made possible by designing and maintaining legislation that ensures a high level of physical protection of nuclear and radiological material used within the state, based on a graded approach. Such legislation should take into account the categorization of nuclear and radiological material and the evaluation of the threat.

For this reason, Morocco has created a new law, 142-12, concerning safety and security and based on the international norms, regulations, and conventions of the IAEA.

The new law addresses the following topics:

- Authorization of the use of nuclear and radiological materials;

- Authorization for transporting nuclear and radiological materials domestically and internationally;

- Waste management;

- Protection against the sources of ionizing radiation; 
- Enhancing the safety and security of nuclear and radiological materials, as well as nuclear facilities;

- Physical protection regimes for nuclear material during transport, use, and storage, and for nuclear facilities;

- Emergency planning;

\section{Opportunities and challenges:}

\section{A. Nuclear Terrorism and The Birth of Subnational Terrorist Groups}

The greatest challenges facing the safety and security of our nation are nuclear terrorism and the development of the terrorist groups which could destroy populations by using nuclear devices. As Dr. Yukiya Amano, director of the International Atomic Energy Agency, said, "Terrorism is spreading and the possibility of using nuclear material cannot be excluded."

Assumptions that terrorists might use nuclear and radiological material to construct bombs should be made in preventing such disasters. How to secure nuclear and radiological material in both private and public society, as well as how to detect such material, especially from afar, should be taken into account as well.

\section{B. Increase Education On Nuclear Security Culture and On Nuclear Security and The Non-Proliferation:}

The security of nuclear and radiological material calls for strong knowledge of nuclear security culture and non-proliferation.

Conducting practical training on nuclear security and preventing insider and outsider threats is vital. As such, the new Moroccan Agency for Nuclear and Radiological Safety and Security should, in cooperation with the IAEA and WINS, create a national center for providing training for those involved in the use of various radiological material.

\section{Establishing an Effective and Efficient Nuclear Security Regulation:}

Establishing effective and efficient nuclear security regulations and conventions is the first responsibility of the new Moroccan Agency for Nuclear and Radiological Safety and Security.

Establishing conventions as to the secure transport of nuclear and radiological material under the new agency will require the operator to ensure nuclear security measures during the transport, use, and storage of nuclear and radiological material in Morocco.

\section{5-Year Plan for Preventing the Proliferation of Weapons of Mass Destruction in Morocco}

In 2016, a young generation of professionals worldwide received a call from the nonpartisan policy research center, The Stimson Center, in cooperation with UNSCR 1540, regarding how to prevent the proliferation of weapons of mass destruction - requesting that professionals submit a 5-year plan for preventing the proliferation of WMDs by examining their own or other countries.

I participated by developing and submitting a 5-year plan for Morocco on August 4, 2016. WMD proliferation - such as nuclear, biological, and chemical weapons - is a real threat posed to international 
security. Unfortunately, in recent years, nuclear terrorism has become a reality for us, and there are numerous terrorists and extremists groups that are rising up around the world. Many of them, as well as individual nations, aim to develop, obtain, and retain WMDs so as to destroy humanity and the environment by using them in their attacks.

Since 1970, the treaty on non-proliferation has been in effect. It was created to prevent the spread of WMDs so as to protect people and environments against the harmful effects that could result from the uses of WMDs. The non-proliferation treaty is based on three principles, pillars that include: the nonproliferation, disarmament, and the peaceful use of nuclear energy and cooperation between the states.

In addition, a variety of nuclear materials used around the world - such as in the medical, industrial, and food fields - have been designated as radiological materials that could be used to make a radiological dispersal device (or a "dirty bomb"), and other nuclear fissile sources such as uranium and plutonium can be used in nuclear reactors. However, it is essential to strengthen nuclear security measures in nuclear facilities and in the organizations that work with nuclear material in order to protect the materials against theft.

The table below lays out a 5-year plan established for the Kingdom of Morocco:

National Plan for the Kingdom of Morocco for the Implementation of Resolution UNSCR 1540 to Prevent the Proliferation of Weapons of Mass Destruction:

Table 2. 5-Year Plan Established to Prevent the Proliferation of Mass Destruction

\begin{tabular}{|c|c|c|c|c|}
\hline Year & National Activity & $\begin{array}{c}\text { National } \\
\text { Stakeholders }\end{array}$ & $\begin{array}{l}\text { International } \\
\text { Stakeholders }\end{array}$ & $\begin{array}{c}\text { UNSCR } \\
1540\end{array}$ \\
\hline $\begin{array}{l}2016- \\
2017\end{array}$ & $\begin{array}{l}\text { 1- Adopt the international } \\
\text { regulations in nuclear security as } \\
\text { national regulations } \\
\text { 2- Control the import/export of } \\
\text { radiological material by air } \\
\text { 3- Train a group of police forces } \\
\text { to protect the border of the state } \\
\text { aimed at combating the illicit } \\
\text { trafficking of radiological and } \\
\text { nuclear material } \\
\text { 4- Establish a guide and national } \\
\text { convention in nuclear security of } \\
\text { radioactive sources } \\
\text { 5- Inspect the national } \\
\text { organizations such as industrial } \\
\text { ones and private/public hospitals } \\
\text { using radiological and nuclear } \\
\text { material }\end{array}$ & $\begin{array}{l}\text { Moroccan Agency for } \\
\text { Nuclear and } \\
\text { Radiological Safety } \\
\text { and Security \& } \\
\text { CNESTEN } \\
\text { Moroccan Agency for } \\
\text { Nuclear and } \\
\text { Radiological Safety } \\
\text { and Security }\end{array}$ & $\begin{array}{l}\text { IAEA Support and } \\
\text { Control }\end{array}$ & $\begin{array}{c}\text { Technical } \\
\text { Support }\end{array}$ \\
\hline
\end{tabular}


Touarsi and Kharchaf: The Future of Nuclear Security in Moroccan Territory After the $\mathrm{Cr}$

International Journal of Nuclear Security, Vol. 3, No. 1, 2017

\begin{tabular}{|c|c|c|c|c|}
\hline \multirow[t]{5}{*}{$\begin{array}{l}2017- \\
2018\end{array}$} & $\begin{array}{l}\text { 1- Safeguard all radiological } \\
\text { material used in the Moroccan } \\
\text { territory }\end{array}$ & $\begin{array}{l}\text { Moroccan Agency for } \\
\text { Nuclear and } \\
\text { Radiological Safety } \\
\text { and Security }\end{array}$ & $\begin{array}{l}\text { IAEA inspection } \\
\text { and safeguarding } \\
\text { WNTI, IAEA }\end{array}$ & Report \\
\hline & $\begin{array}{l}\text { 3- Repatriate category-1 and }-2 \\
\text { radiological material }\end{array}$ & $\begin{array}{l}\text { CNESTEN \& } \\
\text { Moroccan Agency for } \\
\text { Nuclear and } \\
\text { Radiological Safety } \\
\text { and Security } \\
\text { Ministry of Health }\end{array}$ & $\begin{array}{l}\text { Support by the } \\
\text { international expert } \\
\text { collaborations, } \\
\text { U.S. Department }\end{array}$ & \multirow[t]{4}{*}{ Funding } \\
\hline & $\begin{array}{l}\text { 4- Secure and store used } \\
\text { radiological material } \\
\text { 5- Create national center under } \\
\text { the Moroccan Agency for Nuclear } \\
\text { and Radiological Safety and } \\
\text { Security to secure radiological } \\
\text { material }\end{array}$ & $\begin{array}{l}\text { Moroccan Agency for } \\
\text { Nuclear and } \\
\text { Radiological Safety } \\
\text { and Security }\end{array}$ & $\begin{array}{l}\text { Unit of the } \\
\text { Biological } \\
\text { Weapons } \\
\text { Convention in the } \\
\text { biological area } \\
\text { WNTI, IAEA }\end{array}$ & \\
\hline & $\begin{array}{l}\text { 6- Create national center for } \\
\text { securing biological material }\end{array}$ & & & \\
\hline & $\begin{array}{l}\text { 7- Establish a national regulation } \\
\text { in transport security of radioactive } \\
\text { and nuclear material }\end{array}$ & & & \\
\hline \multirow[t]{3}{*}{$\begin{array}{l}2018- \\
2019\end{array}$} & $\begin{array}{l}\text { 1- Ratify supplementary guidance } \\
\text { on the import/export of radioactive } \\
\text { sources regarding the code of } \\
\text { conduct on the safety and security } \\
\text { of the sources }\end{array}$ & \multirow[t]{3}{*}{$\begin{array}{l}\text { Moroccan Agency for } \\
\text { Nuclear and } \\
\text { Radiological Safety } \\
\text { and Security and } \\
\text { Tangier Med harbor; } \\
\text { Ministry of Health }\end{array}$} & $\begin{array}{l}\text { IAEA support and } \\
\text { cooperation w/ the } \\
\text { World Health } \\
\text { Organization unit } \\
\text { of the biological } \\
\text { weapons and the } \\
\text { Organization for } \\
\text { the Prohibition of } \\
\text { Chemical Weapons } \\
\text { in the chemical } \\
\text { area }\end{array}$ & Reporting \\
\hline & $\begin{array}{l}2 \text { - Control the import/export of } \\
\text { radioactive material by sea }\end{array}$ & & & \multirow[t]{2}{*}{ Cooperation } \\
\hline & $\begin{array}{l}\text { 3- Train (in workshops) for } \\
\text { securing biological and chemical } \\
\text { material }\end{array}$ & & & \\
\hline
\end{tabular}




\begin{tabular}{|c|c|c|c|c|}
\hline \multirow[t]{4}{*}{$\begin{array}{l}2019- \\
2020\end{array}$} & $\begin{array}{l}\text { 1- Train and exercise in transport } \\
\text { security of radioactive and nuclear } \\
\text { material }\end{array}$ & $\begin{array}{l}\text { Moroccan Agency for } \\
\text { Nuclear and } \\
\text { Radiological Safety } \\
\text { and Security }\end{array}$ & $\begin{array}{l}\text { IAEA } \\
\text { Collaboration and } \\
\text { Support, WNTI }\end{array}$ & $\begin{array}{l}\text { Funding and } \\
\text { Support }\end{array}$ \\
\hline & $\begin{array}{l}\text { 2- Secure cooperation under the } \\
\text { African Regional Cooperative } \\
\text { Agreement for Research, } \\
\text { Development and Training related } \\
\text { to Nuclear Science and } \\
\text { Technology (AFRA) } \\
\text { 3- Create national center to } \\
\text { control the import/export and use } \\
\text { of biological material }\end{array}$ & $\begin{array}{l}\text { Moroccan Agency for } \\
\text { Nuclear and } \\
\text { Radiological Safety } \\
\text { and Security; national } \\
\text { policy }\end{array}$ & $\begin{array}{l}\text { World Health } \\
\text { Organization, } \\
\text { IAEA }\end{array}$ & $\begin{array}{l}\text { Report; } \\
\text { Funding and } \\
\text { Cooperation }\end{array}$ \\
\hline & $\begin{array}{l}\text { 4- IAEA inspection and } \\
\text { safeguarding }\end{array}$ & & & \\
\hline & 5- Control sea border & & & \\
\hline \multirow[t]{4}{*}{$\begin{array}{l}2020- \\
2021\end{array}$} & $\begin{array}{l}\text { 1- Organize training in transport } \\
\text { security for police force }\end{array}$ & $\begin{array}{l}\text { Moroccan Agency for } \\
\text { Nuclear and } \\
\text { Radiological Safety } \\
\text { and Security, } \\
\text { AMSSNUR, and } \\
\text { CNESTEN }\end{array}$ & $\begin{array}{l}\text { IAEA support by } \\
\text { giving training } \\
\text { establishing an } \\
\text { education program }\end{array}$ & $\begin{array}{l}\text { Support by } \\
\text { changing } \\
\text { expert and } \\
\text { funding } \\
\text { support }\end{array}$ \\
\hline & $\begin{array}{l}2 \text { - Develop a program of } \\
\text { collaboration and cooperation with } \\
\text { European nuclear security council }\end{array}$ & $\begin{array}{l}\text { Moroccan Agency for } \\
\text { Nuclear and } \\
\text { Radiological Safety } \\
\text { and Security, }\end{array}$ & $\begin{array}{l}\text { PNS, WINS, } \\
\text { WNTI }\end{array}$ & \\
\hline & $\begin{array}{l}\text { 3- Raise awareness about the } \\
\text { importance of nuclear security } \\
\text { among the university generation } \\
\text { and support the preparation of } \\
\text { PhDs in nuclear security }\end{array}$ & $\begin{array}{l}\text { CNESTEN, \& } \\
\text { AIGAM }\end{array}$ & & $\begin{array}{l}\text { Cooperation } \\
\text { and support } \\
\text { by group of } \\
\text { experts }\end{array}$ \\
\hline & $\begin{array}{l}\text { 4- Cooperate with other states to } \\
\text { combat nuclear terrorism }\end{array}$ & $\begin{array}{l}\text { Ministry of } \\
\text { cooperation and } \\
\text { foreign affairs, } \\
\text { Moroccan Agency for } \\
\text { Nuclear and } \\
\text { Radiological Safety }\end{array}$ & & \\
\hline
\end{tabular}

Abbreviations:

IAEA: International Atomic Energy Agency

WINS: World Institute for Nuclear Security

WNTI: World Nuclear Transport Institute

AIGAM: Moroccan Association of Engineers in Nuclear Engineering

CNESTEN: National Centre for Nuclear Energy, Science and Technology 


\section{Conclusion and Discussion:}

To achieve a nuclear security regime for radioactive materials and associated facilities and activities, Morocco should maintain the following objectives:

- Protection against unauthorized removal of radioactive materials used in associated facilities and associated activities;

- Protection against sabotage involving radioactive materials, associated facilities, and associated activities;

- Rapid and regulatory control of materials.

\section{Realization}

These objectives call for the creation or enhancement of the legislative and regulatory framework concerning the safety of radioactive materials and related facilities and activities in order to reduce the likelihood of malicious acts.

The development of a nuclear security culture, the strengthening of the regulatory and legislative frameworks, and the development of terrorism, which constantly changes its façades (and which could take the form of aggression against facilities hosting nuclear or radioactive material, or an attack by dispersal of radioactive or other material) make the international cooperation and coordination of international technical nuclear security activities necessary. Such cooperation and coordination will, as well, avoid duplication of efforts and control sensitive exports, reducing the risk that terrorists may have access to materials, equipment, and technology involved in the development of weapons of mass destruction. It will also strengthen computer security (e.g., protection of networks and sensitive information). Lastly, human resources for the sustainable implementation of nuclear security measures should be considered essential as well.

\section{Bibliography}

1. P. Podvig, "Global Nuclear Security Building Greater Accountability and Cooperation" (UNIDIR/2011/9, United Nations Institute for Disarmament Research, Geneva, Switzerland, 2011), (available at http://www.unidir.org/files/publications/pdfs/global-nuclear-security-building-greateraccountability-and-cooperation-383.pdf).

2. Accueil | Agence Marocaine de Sûreté et Sécurité Nucléaires et Radiologiques, (available at http://amssnur.org.ma/).

3 International Atomic Energy Agency, Governmental, legal and regulatory framework for safety: general safety requirements. (2016; http://public.eblib.com/choice/publicfullrecord.aspx?p=4853326).

4. National Academy of Engineering, Prevent Nuclear Terror. NAE Gd. Chall. Eng., (available at http://www.engineeringchallenges.org/challenges/nuclear.aspx).

5. National Progress Report: Morocco. 2016 Nucl. Secur. Summit, (available at http://www.nss2016.org/document-center-docs/2016/3/31/national-progress-report-morocco).

6. K. El Mediouri, Moroccan Experience in Nuclear Sciences and Technology: Present Status (2001) (available at http://inis.iaea.org/Search/search.aspx?orig_q=RN:33004580).

7. Nuclear security culture (Internat. Atomic Energy Agency, Vienna, 2008), IAEA nuclear security series Implementing guide. 